\title{
Ground Penetrating Radar investigation of depositional architecture: the São Sebastião and Marizal formations in the Cretaceous Tucano Basin (Northeastern Brazil)
}

\author{
Arquitetura deposicional investigada por Radar de Penetração \\ no Solo: Formações São Sebastião e Marizal das Sub-bacias do Tucano \\ Sul e Central, Cretáceo (Nordeste do Brasil)
}

\author{
Larissa Natsumi Tamura ${ }^{1 *}$, Renato Paes de Almeida ${ }^{1,2}$, \\ Fabio Taioli ${ }^{1,2}$, André Marconato ${ }^{1}$, Liliane Janikian ${ }^{3}$
}

\begin{abstract}
One key factor for the advance in the study of fluvial deposits is the application of geophysical methods, being the Ground Penetrating Radar one of special value. Although applied to active rivers, the method is not extensively tested on the rock record, bearing interest for hydrocarbon reservoir analogue models. The São Sebastião and Marizal formations were the subject of previous studies, which made possible the comparison of Ground Penetrating Radar survey to previous stratigraphic studies in order to identify the best combination of resolution, penetration and antenna frequency for the studied subject. Eight radar facies were identified, being six of them related to fluvial sedimentary environments, one related to eolian sedimentary environment and one radar facies interpreted as coastal sedimentary environment. The Ground Penetrating Radar data showed compatibility to sedimentary structures in the outcrops, like planar and trough cross-stratified beds. It is noted that the obtained resolution was efficient in the identification of structures up to $0.3 \mathrm{~m}$ using a $100 \mathrm{MHz}$ antenna. In this way, the Ground Penetrating Radar survey in outcrops bears great potential for further works on fluvial depositional architecture.
\end{abstract}

KEYWORDS: radar facies; Ground Penetrating Radar; fluvial system; São Sebastiáo Formation; Marizal Formation.

\begin{abstract}
RESUMO: Um fator-chave para o avanço no estudo de depósitos fluviais é a aplicação de métodos geofísicos, e o Radar de Penetração no Solo é um método de especial valor. Embora amplamente aplicado em ambientes de rios ativos, em ambientes fluviais consolidados esse tipo de estudo é mais escasso, em contrapartida há uma grande importância em mais estudos de modelos análogos de hidrocarboneto. Por essa motivação, o presente trabalho aplicou o Radar de Penetração no Solo em afloramentos já estudados estratigraficamente nas Formaçôes São Sebastião e Marizal e comparou ambos os resultados, além de definir se a resolução, a penetração e a frequência da antena foram adequadas na área de estudo. Por meio dos resultados, é possivel identificar oito radar fácies diferentes, dos quais seis estão relacionadas a ambientes fluviais, uma a ambiente cólico, e a última a ambiente costeiro. Observou-se que houve compatibilidade entre os refletores encontrados nas seçōes Radar de Penetração no Solo e as estruturas sedimentares observadas em afloramento, como conjuntos de estratos cruzados preenchidos por estruturas planares ou acanaladas. Nota-se que a resolução do método foi muito eficiente e identificou estruturas decimétricas de até 0,3 m com uma antena de $100 \mathrm{MHz}$, porém com menor penetração de sinal em comparação com trabalhos de rios ativos. Dessa forma, o Radar de Penetraçáo no Solo mostrou-se de grande potencial para estudos futuros sobre a arquitetura deposicional das unidades investigadas.
\end{abstract}

PALAVRAS-CHAVE: radar fácies; Radar de Penetração no Solo; sistema fluvial; Formação São Sebastiāo; Formação Marizal.

\footnotetext{
${ }^{1}$ Instituto de Geociências, Universidade de São Paulo - USP, São Paulo (SP), Brazil. E-mail: larissa.natsumi@gmail.com, andre.marconato@usp.br ${ }^{2}$ Instituto de Energia e Ambiente, Universidade de São Paulo - USP, São Paulo (SP), Brazil. E-mail: rpalmeid@usp.br, ftaioli@usp.br ${ }^{3}$ Departamento de Ciências do Mar, Universidade Federal de São Paulo - UNIFESP, Santos (SP), Brazil. E-mail: lijanikian@gmail.com *Corresponding author.

Manuscript ID: 20150031. Received in: 09/04/2015. Approved in: 01/13/2016
} 


\section{INTRODUCTION}

The Ground Penetrating Radar (GPR) is a geophysical method that uses high frequency electromagnetic waves to create high resolution imagery, making it possible to recognize sedimentary structures through patterns and terminations of reflectors (Neal 2004). As a result, the interpretation of radar facies from GPR data is frequently used in the interpretation of sedimentary structures in active river deposits (e.g. Gawthorpe et al. 1993, Best et al. 2003, Skelly et al. 2003, Wooldridge \& Hickin 2005, Sambrook Smith et al. 2006, 2009), being responsible for substantial advances in the characterization of the internal structure of bars.

Studies that used GPR as a tool to interpret sedimentary structures in fluvial deposits date back to Gawthorpe et al. (1993), which introduced the concept of radar facies in fluvial environments through the use of interpretation techniques similar to seismic surveys. Recent works (e.g. Best et al. 2003, Sambrook Smith et al. 2009) use an approach based on the combination of a series of survey lines in active rivers, parallel and perpendicular to the river flow, in order to build depositional models of fluvial bars.

Notwithstanding the importance of this technique, it has being seldom applied on ancient fluvial deposits. One of the few studies that used GPR on outcrops was carried by Corbeanu et al. (2001), who surveyed fluvial channel deposits from the Coyote Basin, USA. The authors determined four radar facies based on the termination of reflectors and signal amplitude, which enabled further classification of the sedimentary units.

The target study area includes outcrops of the São Sebastiāo and Marizal formations, Barremian and Aptian (respectively) of the Tucano Basin, Northeastern Brazil, which were previously studied in regard to the depositional architecture of the deposits (Figueiredo 2013, Freitas 2014, Figueiredo et al. 2015, Carrera 2015). The quality of the exposures and the existence of previous sedimentological studies make the area an ideal target for studies regarding the applicability of geophysical surveys to the investigation of fluvial depositional architecture in sedimentary rocks, with implications for hydrocarbon reservoir analogue studies (Tatum \& Francke 2012).

The main goal of this study was to enhance the interpretation tools of radar facies through the comparison of GPR data to sedimentary structures and architectural elements visible in outcrops of the same beds, considering the resolution and limitations of the method, so that it can be assessed if GPR surveys can be securely used in locations deprived of outcrop exposure.

\section{GEOLOGICAL SETTING}

The Tucano Basin is located at the Brazilian northeast, and is the main basin in the Recôncavo-Tucano-Jatobá (RTJ) rift, with an exposed area in excess of $45,000 \mathrm{~km}^{2}$. The onset of the basin is related to early stages of the South Atlantic opening, at the beginning of the Cretaceous (Magnavita et al. 2003). The rift can be subdivided in the north, central and south sub-basins, bounded by the Vaza-Barris and Itapicuru structural highs. Shifts in the position of the master faults between the north and central sub-basins caused shifting of depocenters (Milani \& Davison 1988; Fig. 1).

The sedimentary succession deposited throughout the evolution of the RTJ rift reaches a total thickness near 10,000 m, deposited between the Neocomian and the Barremian. The basin encompasses alluvial fan deposits (Salvador Formation), lacustrine deposits (Candeias Formation), deltaic deposits (Ilhas Group), and fluvial deposits (São Sebastião Formation) (Magnavita 1992, Magnavita et al. 1994, Costa et al. 2007a, 2007b), covered by the Marizal Formation, a thin succession of fluvial deposits with a record of marine incursion (e.g. Arai 2014, Amaral \& Brito 2012), deposited during a late reactivation of the rift (Figueiredo et al. 2015).

Among the sedimentary units found in the rift, the São Sebastiáo and Marizal formations have the best exposures, encompassing essentially sandstone and conglomerate, with limited siltstone and carbonate, interpreted as fluvial, alluvial fan and lacustrine depositional systems (e.g. Magnavita \& Cupertino 1988, Milani \& Davison 1988, Costa et al. 2007a, 2007b, Freitas 2014).

The São Sebastião Formation has limited exposures at the basin border and at the Vaza-Barris River valley. The sedimentary succession is laterally interfingered to the Salvador Formation (Viana et al. 1971), has a transitional contact to Ilhas Group at the base (Santos et al. 2010), and bears conglomeratic sandstone, with subordinate mudstone and heterolithic beds, reaching a thickness up to 3,000 m (e.g. Costa et al. 2007a, 2007b, Santos et al. 2010, Figueiredo et al. 2015). The age of the succession ranges from the Barremian to the early Aptian, according to its ostracode content (Viana et al. 1971). The majority of the deposits represent fluvial bars, formed by tabular beds with inclined, meter scale crosssets, often with convoluted beds, which locally are covered by fine-grained sandstone, siltstone and heterolithic beds, interpreted as bar top and small channel deposits, with rare record of large scale cross-stratified sandstone, interpreted as eolian dunes deposits (Figueiredo 2013).

The up to $300 \mathrm{~m}$ thick Marizal Formation overlies the São Sebastião Formation on a regional unconformity, being bounded at the top by carbonates from the Santana Formation in the North Tucano sub-basin and the Jatobá 


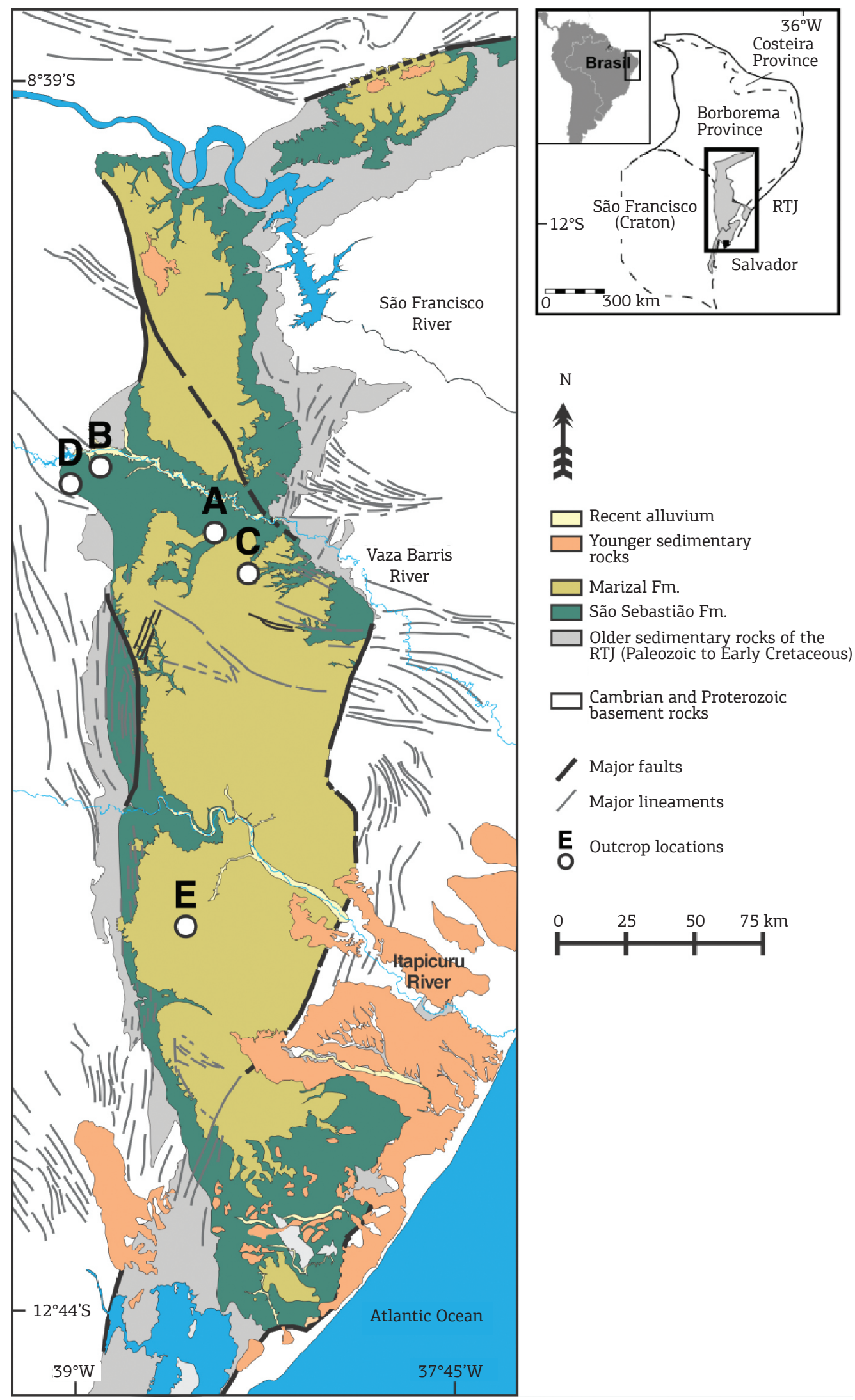

Figure 1. Geographic location of the Recôncavo-Tucano-Jatobá rift and geologic sketch of the basin (after Freitas 2014). 
Basin (Magnavita et al. 2003, Costa et al. 2007a, 2007b, Silva et al. 2007, Santos et al. 2010). The sedimentary succession is Aptian in age, determined by its fossil content of palinomorphs, fish and ostracode (Almeida Filho et al., 2002; Reis et al., 2007; Alvarado-Ortega \& Brito, 2010; Amaral \& Brito, 2012). The base of the Marizal Formation records a large scale river, bearing sandstone deposits with large-scale inclined cross-sets, with subordinate mudstone and heterolithic beds (Freitas, 2014, Almeida et al., 2015), which is covered by a marine incursion, represented by mudstone and heterolithic beds, with renown fossil assemblage (Almeida Filho et al., 2002; Reis et al., 2007; AlvaradoOrtega \& Brito, 2010; Amaral \& Brito, 2012). The upper part of the Marizal Formation records unconnected fluvial channel deposits isolated by proximal and distal floodplain deposits, with the larger channel deposits being similar to the sandstone deposits found at the base of the succession (Freitas 2014).

Composition of the siliciclastic rocks of the Marizal Formation is notably less mature than the Sáo Sebastiáo Formation, with sandstone tending to be richer in feldspar and lithic fragments, which is also reflected in the richer variety of lithotypes found in the conglomerates of the Marizal Formation in comparison to the quartz rich conglomerates of the São Sebastiáo Formation (Freitas 2014, Figueiredo et al. 2015).

\section{METHODOLOGY}

\section{Ground Penetrating Radar}

The GPR is a non-destructive geophysical method that uses high frequency electromagnetic waves, in the $10 \mathrm{MHz}$ to $2.5 \mathrm{GHz}$ range. Pulses of electromagnetic waves are generated by a transmitting antenna into the ground and reflected waves are captured by a receiver antenna also placed on the surface (Gawthorpe et al. 1993). Such setting allows the GPR to achieve high resolution images of the shallow subsurface. The data are simultaneously displayed at a control station and recorded in hard drive (Porsani 2011).

The chosen setup for this study is the Common Offset, which used a pair of $100 \mathrm{MHz}$ RIS antennas, manufactured by IDS. The starting parameters were inserted in the acquisition software K2, with record length of 250 ns, 512 samples/scan, and an offset of $4.8 \mathrm{~cm}$. The antenna offset remained constant, which enabled real time visualization of the profiles.

The velocity values were obtained from the hyperboles found in the profiles $(\mathrm{v}=0,11 \mathrm{~m} / \mathrm{ns})$. The obtained values were also concordant with values found in the literature for sandstones (Jol \& Bristow 2003).
The data was later processed in the Reflexw software, which included the correction of the zero time, dewow, adjustment of gain, filters (bandpass and $\mathrm{f}-\mathrm{k}$, frequency wavenumber), topographic correction.

\section{Interplay between resolution, signal penetration and antenna frequency}

One relevant feature arises from the interplay between the penetration depth and frequency employed for each situation. The depth of penetration and the profile image resolution are inversely proportional and dependent on the employed frequency. In this way, it is necessary to delimit the size of the targeted subject in order to determine the most suitable frequency for a given survey.

When using high frequency antennas, the obtained resolution will be high, however with shallow penetration, while when using low frequency antennas, the result will be opposite (Tab. 1). The depositional environment and pore saturation might as well impair the signal penetration (Tab. 2).

The vertical resolution is the property related to the distinction of two signals adjacent in time, which is directly related to the antenna frequency (Reynold 1997). The ideal theoretical vertical resolution is described as a quarter of wavelength. Inside such vertical length some reflections will

Table 1. Interplay between antenna frequency and depth of penetration (Annan 2001).

\begin{tabular}{c|c}
\hline Center frequency $(\mathbf{M H z})$ & Depth(m) \\
\hline 1000 & 0.5 \\
\hline 500 & 1 \\
\hline 200 & 2 \\
\hline 100 & 7 \\
\hline 50 & 10 \\
\hline 25 & 30 \\
\hline 10 & 50 \\
\hline
\end{tabular}

Table 2. Speed and signal attenuation relative to changes in lithology and pore saturation for antennas with frequencies in the 80 to $120 \mathrm{MHz}$ range (adapted from Neal 2004).

\begin{tabular}{l|c|c}
\hline Lithology & Velocity $(\mathrm{m} / \mathrm{ns})$ & $\begin{array}{c}\text { Attenuation } \\
(\mathbf{d B} / \mathbf{m})\end{array}$ \\
\hline Unsaturated sand & $0.1-0.2$ & $0.01-0.014$ \\
\hline Saturated sand & $0.05-0.08$ & $0.03-0.05$ \\
\hline Unsaturated clay & $0.09-0.12$ & $0.028-300$ \\
\hline saturated clay & $0.05-0.07$ & $0.028-300$ \\
\hline
\end{tabular}


constructively interfere with each other, resulting in one single observable reflector (Tab. 3; Neal 2004).

The vertical resolution of the radar reflection profile has a relevant implication for sedimentological interpretation, as the property determines the scale of observable sedimentary structures. Considering that each laminated bed has a thickness below $0.01 \mathrm{~m}$, and that a high frequency antenna surveying a material with low signal loss, such as sand, will reach a maximum resolution in the 0.02 to $0.08 \mathrm{~m}$ range, it is possible to determine only the main surfaces or a set of laminated beds, and not each discrete laminated bed (Neal 2004).

\section{Radar facies interpretation}

The concept of radar facies is based on the methodology applied to seismic stratigraphy surveys. The interpretation techniques are the same for both methods, even with such different reflectors scales. The main reason behind this is that for clastic sedimentation the contrasting physical properties that produce reflectors are the same irrespectively of the scale of the survey. Also, the geometrical behavior of hierarchical features is similar both for very small scales (such as lamination) and sedimentary basin scales. Thus, the terminology used for radar facies is similar to the terminology used for seismic stratigraphy surveys, with minor modifications. According to Neal (2004) and Gawthorpe et al. (1993), the features can be classified based on the shape of the reflection, the dip of the reflection, the amplitude of the reflection, and the relation between the reflections and their continuity.

Considering the resolution applied for GPR surveys, it is possible to interpret sedimentary facies and facies associations through the reflection profile of the radar, which are useful for the interpretation of depositional environments (Neal 2004). In the present study, structures directly observable in outcrops were imaged with GPR in order to access the interpretation potential and of the technique when applied to the rock record, and to compare the results with published data on unconsolidated deposits from similar depositional environments.

Table 3. Antenna frequencies and their corresponding vertical resolution (Porsani 2011).

\begin{tabular}{c|c}
\hline Center frequency (MHz) & $\begin{array}{c}\text { Theoretical vertical } \\
\text { resolution }(\mathbf{m})\end{array}$ \\
\hline 200 & $0.125-0.25$ \\
\hline 100 & $0.25-0.5$ \\
\hline 50 & $0.5-1.0$ \\
\hline 25 & $1-2$ \\
\hline
\end{tabular}

\section{RESULTS}

\section{Comparison between radar facies and sedimentary structures found on outcrops}

The GPR surveys were obtained at the South- and CentralTucano sub-basins, with locations summarized in the Figure 1.

In order to assess the reliability of the radar facies interpretations, a set of outcrops was surveyed (Fig. 1), which were the subject of previous studies regarding the sedimentology and architecture of the deposits (Figueiredo 2013, Freitas 2014, Figueiredo et al. 2015, Carrera 2015), so that the direct comparison to the GPR data were possible.

\section{Point A}

This outcrop is a fresh road cut of the BR-235 road, located near the locality of Brancos, at the municipality of Jeremoabo, Bahia, with its medium- to coarse-grained sandstone deposits attributed to fluvial bars of the São Sebastião Formation (Figueiredo 2013). Three GPR profiles were obtained right beneath the outcrop walls, two of them nearly parallel to the paleocurrent direction, while the third one was obtained in an oblique direction. The western part of the outcrop is dominated by medium-grained sandstone with sparse granules, organized in trough cross-sets 15 to $35 \mathrm{~cm}$ thick, with paleocurrent approximately parallel to the survey. The structures were detected by the GPR as reflectors representing inclined and sub-horizontal bounding surfaces. Towards the eastern side of the outcrop, the profile (Fig. 2) shows sets of planar cross-stratified sandstone, with discrete segregation of very coarse-grained sandstone at the cross-bedding, which shifts laterally to very coarse-grained sandstone arranged in cross-sets thicker than $1.5 \mathrm{~m}$. The GPR survey was successful at detecting radar facies that could be directly correlated to outcrop structures, in this case the large-scale cross-sets. However, it was also suggested sedimentary structures that could not be correlated to the nearby outcrop, which include reflectors interpreted as inclined and parallel bounding surfaces of planar cross-sets (Fig. 3). The last profile, obtained in an oblique direction between the two previous profiles, reveals medium- to coarse-grained sandstone, with sparse granules and pebbles, with strong grain segregation. The cross sets are at least $2 \mathrm{~m}$ thick, with planar cross-stratification marked by strong grain sorting (Fig. 4).

The profiles have sufficiently high resolution to make possible the identification of sedimentary beds and their internal structures, like trough and planar features. There was reasonable penetration of the radar signal, which reached $4.5 \mathrm{~m}$ depth in the first profile. In a few small segments of the profile, the radar signal is absent, which can be explained by the roughness of the rocky surface. 


\section{Point B}

The next outcrop is located at the municipality of Canudos, Bahia, in the Vaza Barris river valley, which are attributed to the São Sebastião Formation, interpreted by Figueiredo (2013) as deposits of fluvial bars. The survey was undertaken right on top of the outcrop, which shows medium- to coarse-grained sandstone with inclined planar cross-sets $20 \mathrm{~cm}$ thick. At the upper half of the profile a laterally continuous surface, positioned less than $1 \mathrm{~m}$ from the top, separates a series of inclined cross-sets from an overlying series of cross-sets with low-angle bounding surfaces. The GPR profile (Fig. 5) depicts the same surface as a continuous, slightly concave upwards reflector, above which other reflectors onlap. The majority of the reflectors represents cross-sets bounding surfaces, with a few recognizable low amplitude reflectors, which suggest that the imaged cross-strata are near the limit of detection of the survey.

The signal penetration was shallow, reaching up to $2 \mathrm{~m}$, and the resolution was also poor, although some low amplitude trough structures are still visible between low angle

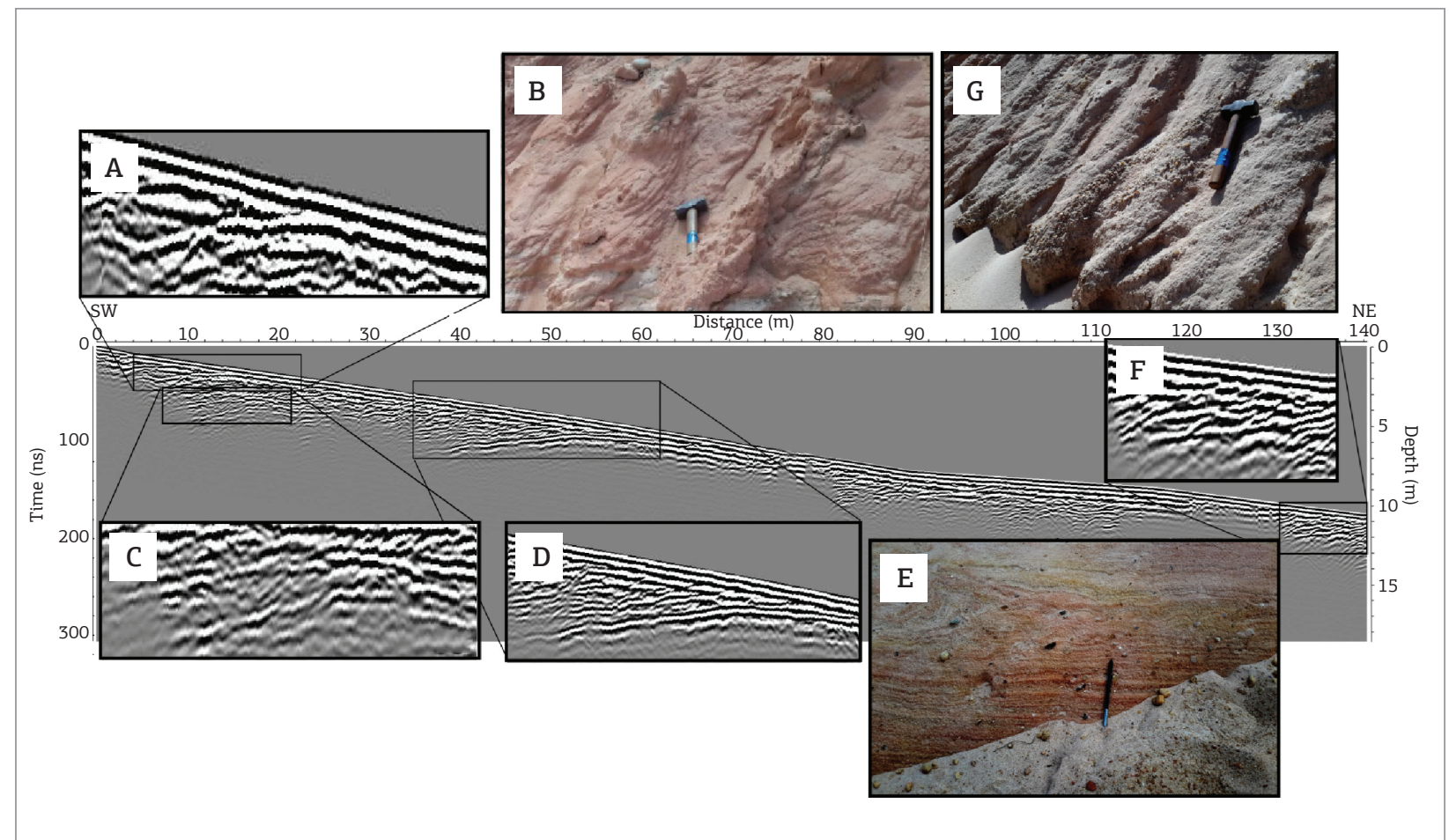

Figure 2. Ground Penetrating Radar survey at Point A, Profile I. Four different patterns of reflectors are ascribed to sedimentary structures: (A - B) trough cross-strata sets with inclined set boundaries; $(C)$ not exposed, which is interpreted as inclined set boundaries between planar cross-strata; (D - E) boundaries of large scale planar crossstratified beds; ( $-F)$ coarse-grained sandstone, with bed thickness in excess of $1.5 \mathrm{~m}$.

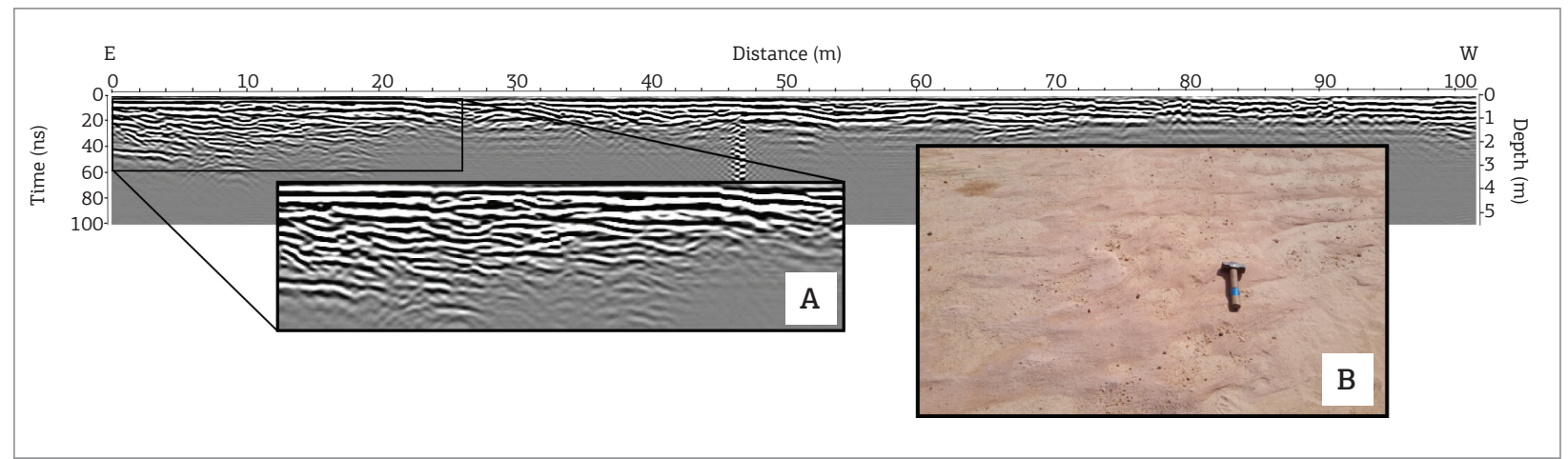

Figure 3. Ground Penetrating Radar survey at the Point A, Profile II. Both the Ground Penetrating Radar profile (A) and the outcrop (B) shows sub-horizontal surfaces bounding trough cross-stratified beds. 
reflectors. The shallower signal penetration combined to the loss of resolution in the acquisition can be the result of water saturation of the substrate, due to precipitation during the Ground Penetrating Radar survey.

\section{Point C}

This is outcrop is located at the municipality of Jeremoabo, Bahia, bearing sandstone and conglomeratic sandstone from the São Sebastião Formation, interpreted as the record of fluvial bars by Figueiredo (2013). The survey was made parallel to the outcrop depicted in Figure 6, at a distance of about $15 \mathrm{~m}$ from the outcrop walls, at the other side of the road.
The outcrop bears 20 to $35 \mathrm{~cm}$ thick sets of planar cross-stratified sandstone, bounded by gently inclined surfaces. A number of these bounding surfaces can be seen at the GPR profile, although the interval between the interpreted surfaces is larger than what is observed at the outcrop. This could be an artifact of insufficient resolution of the survey, which resulted also in a lack of detection of any cross-strata. The truncation found among reflectors and the onlapping against meter sized concave-upwards reflectors were interpreted as the infilling of channelized features, which were in turn compatible to channels filled by laminated and cross-stratified sandstone found at the outcrop.

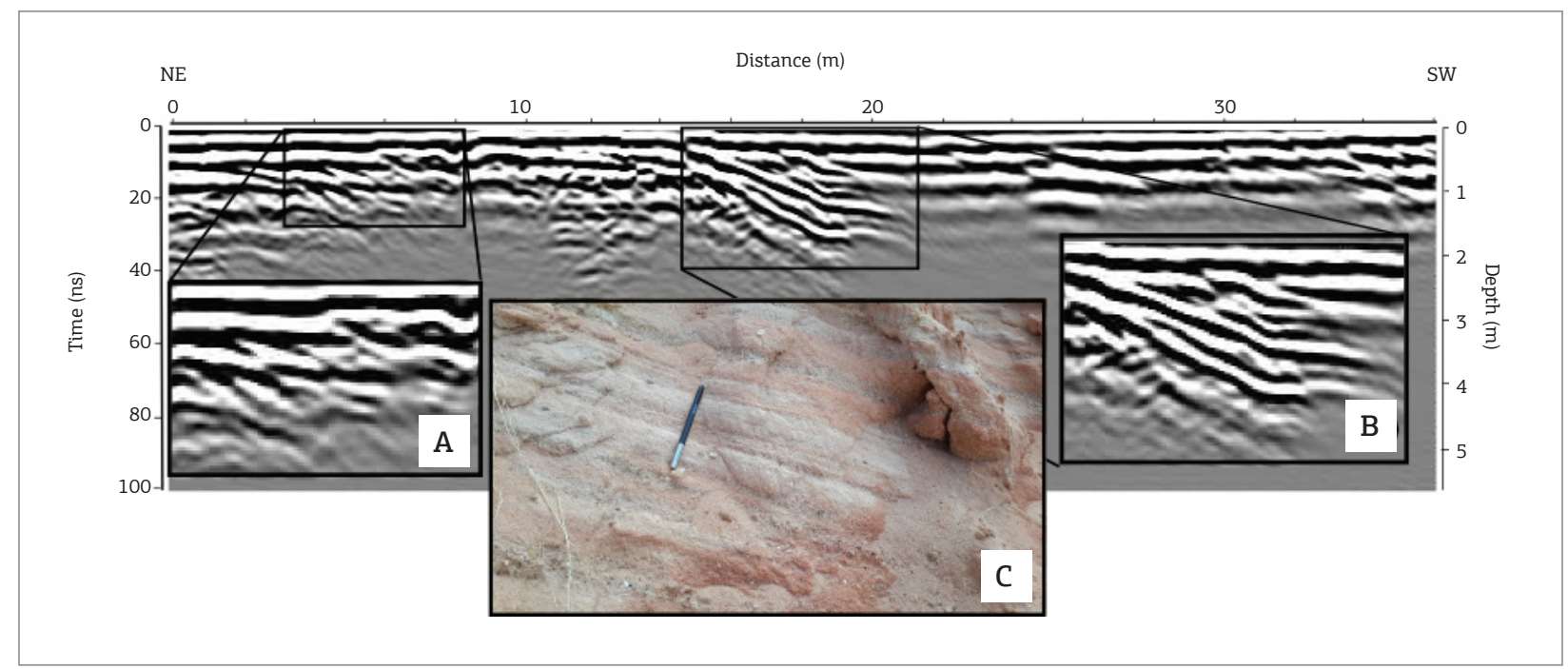

Figure 4. Ground Penetrating Radar survey at the Point A, Profile III. Two different patterns of reflectors can be identified: (A) not exposed plane-bedding bounding surfaces to planar cross-stratified beds; (B) high angle inclined reflectors, correspondent to outcrop in Fig. 4c; (C) planar cross-stratified beds at least $2 \mathrm{~m}$ thick, with strong grain segregation on the foresets.

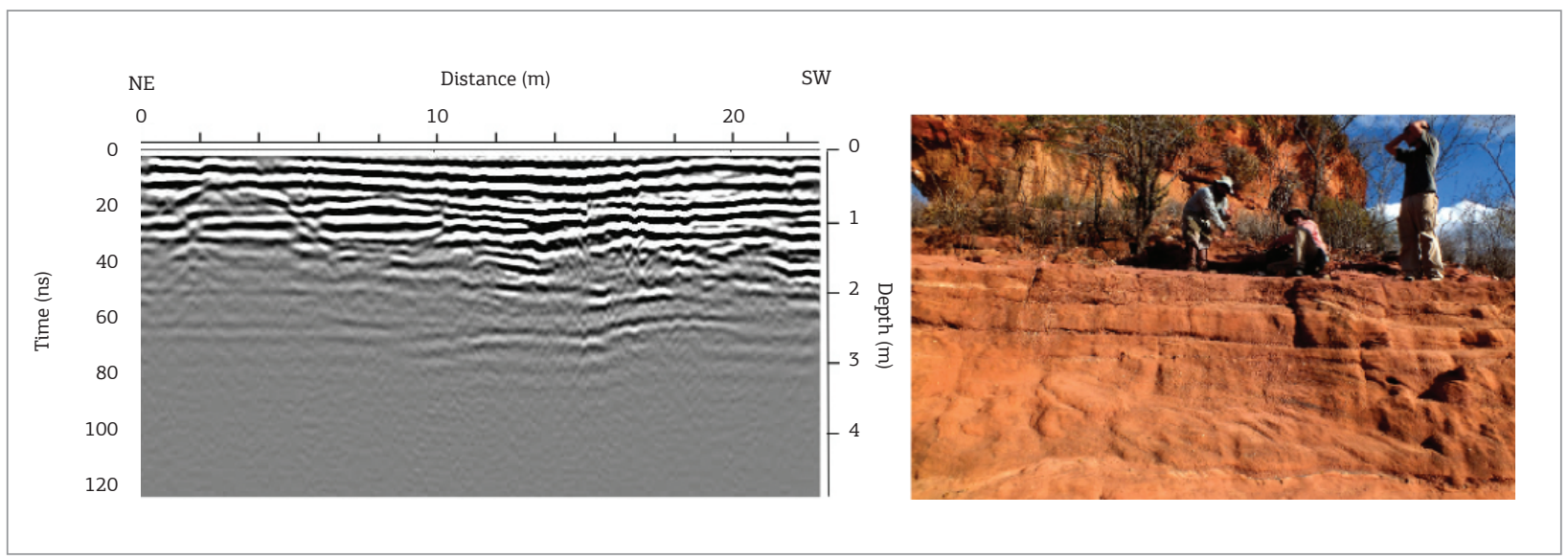

Figure 5. The Ground Penetrating Radar profile was obtained approximately at the same level as the crew on the picture. The lower part of the profile shows inclined cross-sets, which are truncated at the depth of $80 \mathrm{~cm}$ by a set of low-angle reflectors. The high amplitude reflectors are interpreted as set boundaries, while low amplitude reflectors are recognized as cross-stratification. 
Both the signal penetration and the resolution were poor, failing to sample sedimentary structures at the centimeter scale, like cross-bedded stratasets, with only metric scale channelized geometries being imaged. This profile was the only one obtained on a dirt road, in contrast to the profiles obtained directly over the rocky surface.

\section{Point D}

The outcrop is located at environmental protected area Toca Velha das Araras, at the vicinity of the municipality of Canudos, Bahia. The outcrop consists of fine-grained sandstone cemented by iron oxide and large scale crossstrata, from the São Sebastião Formation and interpreted as eolian dune deposits by Figueiredo (2013). The fine-grained sandstone is well sorted, with cross-stratified bed thickness ranging from 2 to $6 \mathrm{~m}$, predominantly planar, with reactivation surfaces and pin-stripe lamination. In addition of the large scale cross-strata, plane-bedding fine-grained sandstone is also present, indicating preservation of interdune deposits. The main sedimentary structures, namely the large scale cross-stratification of the eolian dunes and the nearly horizontal, planar bedding of the interdune deposits, can be identified in the GPR profile (Fig. 7). The sedimentary structures are depicted by large amplitude reflectors in steep angles with $5 \mathrm{~m}$ spacing, while the onlap reflectors represent interdune intervals.

This profile had the deepest penetration of the radar signal, reaching depths up to $5.0 \mathrm{~m}$. One possible explanation lay on the fact that this is the only profile on eolian deposits, which has better sorting and lower content of clay matrix and detritic feldspar grains. In spite of that, there is a segment with a complete loss of signal, in a topographic low, which might have been water saturated due to previous day rain.

\section{Point E}

This outcrop is found near the locality of Raso, at the South Tucano sub-basin, and is positioned in the Marizal Formation, with its fine-grained sandstone deposits interpreted as wave dominated coastal deposits by Freitas (2014). The medium- to large-scale geometry of the deposits is

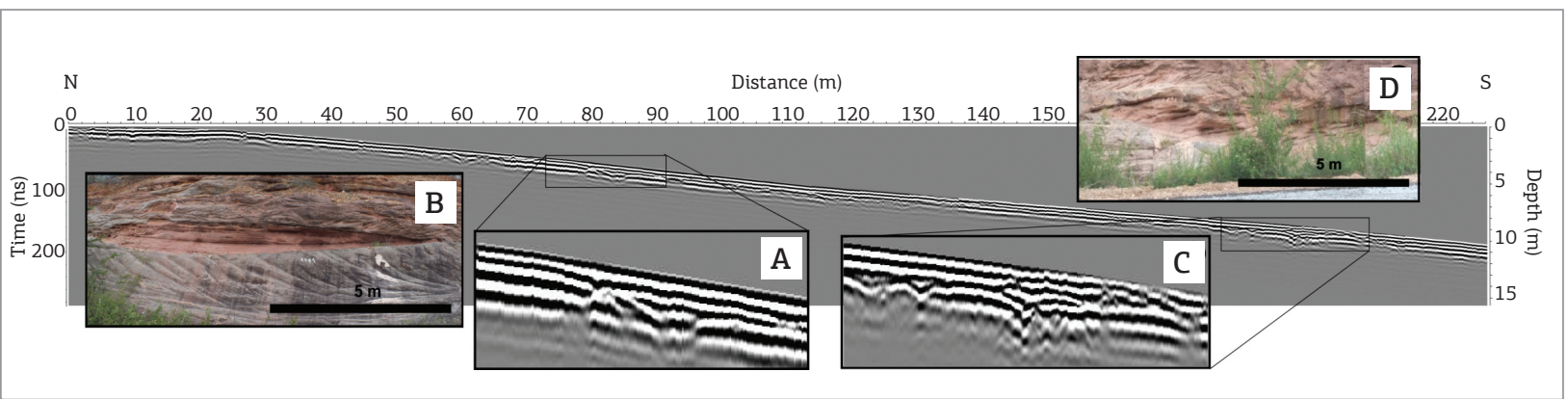

Figure 6. Ground Penetrating Radar profile at the Point C, with details of two of the main channel forms (A and C) and their corresponding outcrop (B and D, respectively), showing truncations among the reflectors and onlap terminations against concave-up reflectors (Figueiredo 2013).

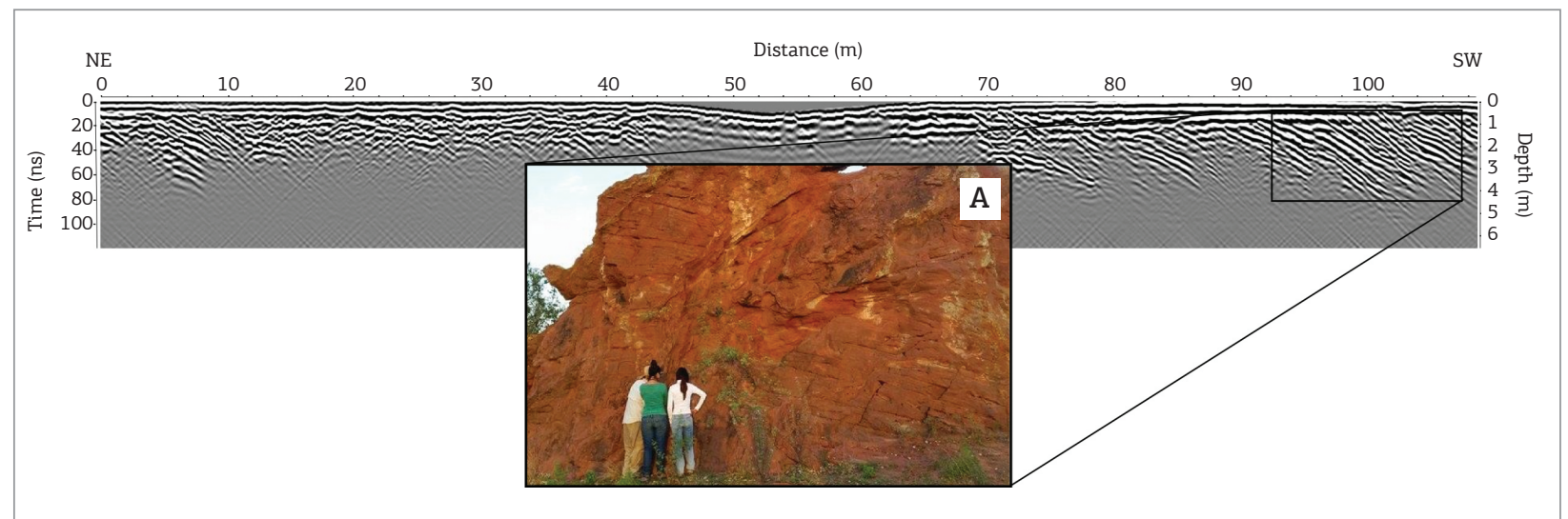

Figure 7. Ground Penetrating Radar survey at Point D. The profile allows the identification of large scale cross stratification $(\mathrm{A})$, with reactivation surfaces. The deeper penetration of the radar signal enabled the recognition of cross-strata up to $5 \mathrm{~m}$ thick. Sub-horizontal reflectors interpreted as plane-bedding lamination and the toplap truncation of inclined reflectors suggest erosive basal surfaces for the interdune deposits. 
assessable at the outcrop, which is dominated by sandstone with low-angle cross-stratification, planar-bedding, and cross-laminated sandstone. The GPR profile (Fig. 8) depicts undulated reflectors with low-angle truncations, which are interpreted as correspondent to the main bounding surfaces of the deposits. Sedimentary structures of centimeter scale, like the cross-laminations, are below the resolution of the survey, and thus are not present in the profile.

The penetration of the radar signal was relatively shallow, with low resolution. As a result, only the bounding surface of cross-laminated beds was imaged. The reflectors were identified as wavy reflectors with low-angle truncations. This was the only profile in the Marizal Formation where the GPR had enough resolution to identify sedimentary structures, which was also the only profile in this study interpreted as deposited in a coastal environment, which would result in better sorting and mineral maturity than in a fluvial deposit.

\section{Radar facies}

Eight radar facies were described, some of which have the same environmental interpretation since they are set together in the outcrop, although they may bear particular angle and reflector termination, which were used as criteria for their distinction.

\section{1 - Low angle inclined reflectors or 2 - Well- defined continuous horizontal reflectors with internal low amplitude inclined reflectors}

Description: 1 - Sets of high amplitude reflectors with low-angle inclination or 2 - sets of well-defined continuous horizontal reflectors, with spacings close to $0.5 \mathrm{~m}$ (Tab. 4). These reflectors bound sets of low amplitude reflectors, which have steeper inclination and decimeter spacing. The depth of investigation was below $4 \mathrm{~m}$.
Interpretation: The high amplitude reflectors represent surfaces bounding sets of planar cross-stratified beds, which in turn are related to the low amplitude reflectors. The bounding surfaces are interpreted as the result of migration of subaqueous dunes, while the cross-sets are the result of partial preservation of the lee side of $2 \mathrm{D}$ subaqueous dunes. 1 - The inclination of the bounding surfaces to the same direction as the cross-sets indicates migration of dunes on the downstream flanks of a fluvial bar, with downstream accretion. 2 - The parallel setting of the set boundaries indicates the dune migration orthogonal to the GPR profile.

\section{3 - Low angle inclined reflectors or 4 - Sub-horizontal, high amplitude reflectors with internal low amplitude concave up discontinuous reflectors}

Description: Sets of high amplitude reflectors and spacings between reflectors around $0.5 \mathrm{~m} 3$ - inclined at low-angles or 4 - showing sub-horizontal inclination (Tab. 4). The high amplitude reflectors bound low amplitude reflectors with discontinuous concave-up shape, and lateral continuity of 1 to $2 \mathrm{~m}$. The depth of penetration of the radar signal was close to $4 \mathrm{~m}$.

Interpretation: The high amplitude reflectors represent low-angle set boundaries, which bound trough cross-sets, represented by the low amplitude, discontinuous, concave-up reflectors. The set boundaries are interpreted as the result of dune migration, while the trough cross-sets are the record of the lee side of 3D dunes. 3 - The subtle inclination of the set boundaries in the same direction as the trough crosssets is suggestive of migration on the downstream flanks of fluvial bars. 4 - The parallel setting of the high amplitude reflectors indicates also that the GPR profile is orthogonal to the paleoflow.

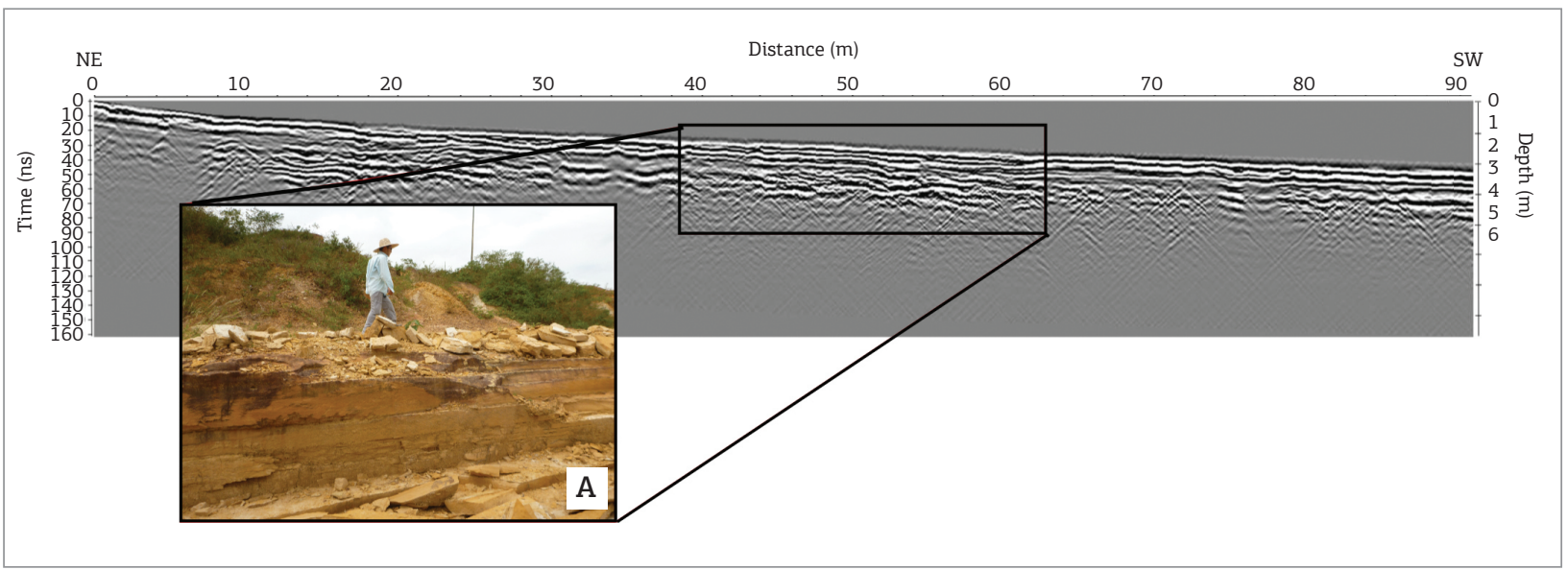

Figure 8. Ground Penetrating Radar survey at the Point E. The outcrop (A) has beds with low-angle cross-stratification that are correlated to the undulated reflectors with low-angle truncations at the Ground Penetrating Radar profile. Features at smaller scale, like ripple marks and cross-laminations, are below the resolution of the survey. 
Table 4. Summary of the radar facies identified in this study, with correspondent description and interpretation. Each radar facies has a Ground Penetrating Radar profiles combined with line drawing of the correspondent geological interpretation.

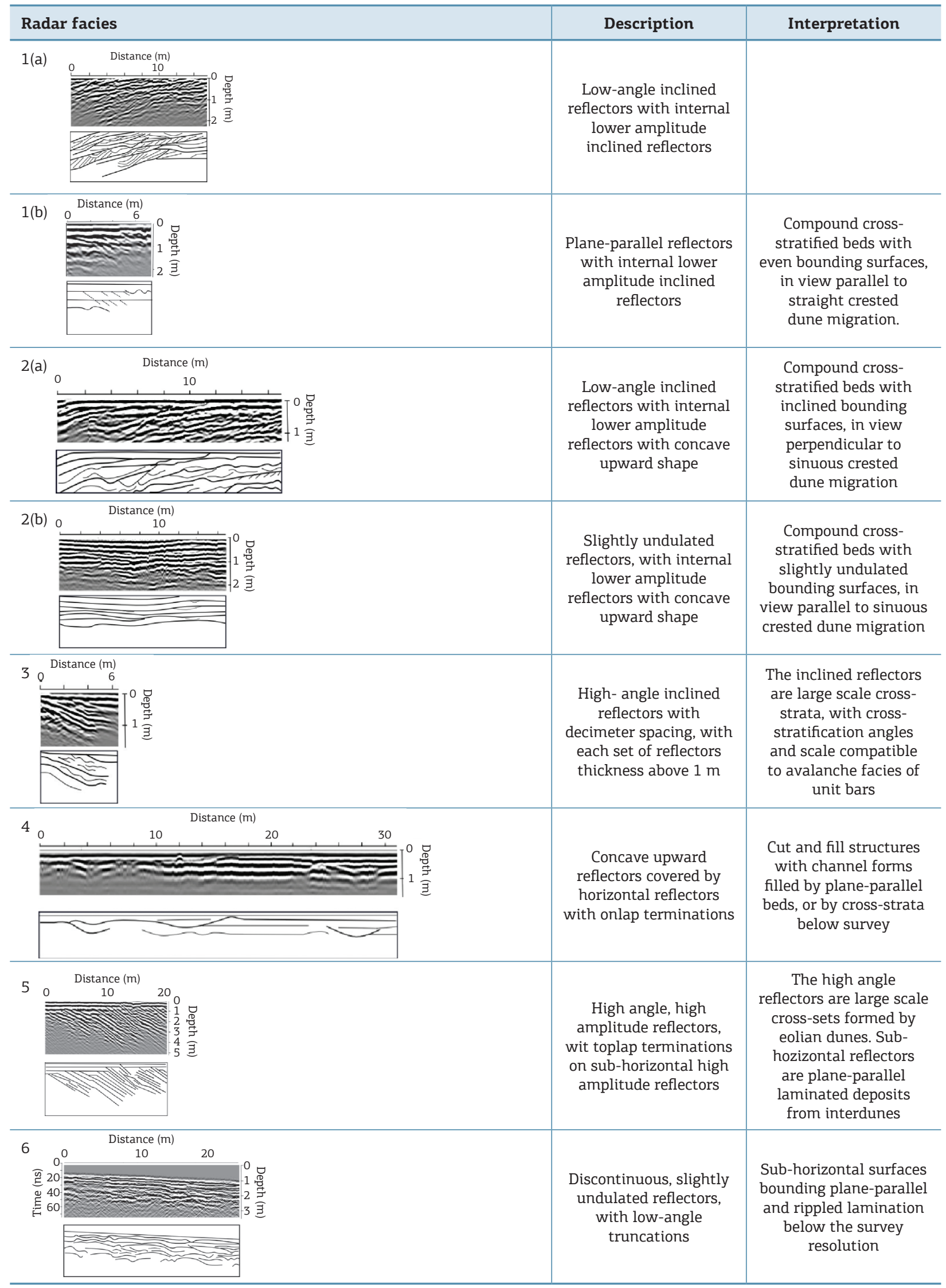




\section{5 - High angle inclined reflectors disposed in meter sets}

Description: Sets of high amplitude reflectors inclined at a steep angles and with decimeter spacing, which is often more than $1 \mathrm{~m}$ thick (Tab. 4). Discontinuous and smaller reflectors can be found locally, with onlap terminations on the high amplitude continuous reflectors. The depth of the signal reached $2.5 \mathrm{~m}$.

Interpretation: The high amplitude inclined reflectors are interpreted as large-scale cross-bedding. The steep angle and the thickness of the cross-sets, in excess of $1 \mathrm{~m}$, are compatible with avalanche foresets in unit bars. The smaller and discontinuous reflectors are attributed to subtle variations in the direction or inclination of the bar faces, thus associated to reactivation surfaces.

\section{6 - Slightly undulated concave-up reflectors covered by horizontal reflectors with onlap terminations}

Description: Sets of reflectors with concave-up shape, often discontinuous, that have a lateral extent larger than $2 \mathrm{~m}$ (Tab. 4). Inside the concave-up reflectors there are series of planar reflectors with onlap terminations and spacing of approximately $0.3 \mathrm{~m}$. This depth of the profiles was close to $2 \mathrm{~m}$.

Interpretation: The concave-up shapes are interpreted as cut-and-fill channel-shaped structures, while the internal reflectors with onlap terminations are the infilling of the channel scours by deposits with plane-bedding, or cross-sets that have thickness below the method resolution. Thus, this radar facies is interpreted as abandoned small channels, filled by sandstone or mudstone, in a fluvial bar top setting.

\section{7 - Meter-scale high amplitude high angle inclined reflectors}

Description: Sets of high amplitude reflectors with high angle inclined reflectors. The spacing between high amplitude reflectors is up to $0.5 \mathrm{~m}$ (Tab. 1). The high amplitude reflectors have toplap terminations against a set of sub-horizontal reflectors with decimeter spacing. The depth of the survey was slightly over $5 \mathrm{~m}$.

Interpretation: The inclined reflectors are interpreted as the result of large-scale cross-strata formed by aeolian dunes. The sub-horizontal reflectors are interpreted as even, parallel laminated deposits of interdune settings. The toplap termination of the high amplitude reflectors indicates erosive surfaces at the base of interdunes.

\section{8 - Slightly undulated reflector with low-angle truncations}

Description: Sets of continuous undulated reflectors, with some of the reflectors presenting low-angle truncations, and spacing between the reflectors of nearly $0.5 \mathrm{~m}$ (Tab. 4). The depth of penetration of the radar signal did not surpass the $2.5 \mathrm{~m}$ mark.

Interpretation: The undulated reflectors are interpreted as sub-horizontal surfaces bounding cross strata with thickness below the resolution of the survey. These sandstones were interpreted as wave dominated coastal deposits by Freitas (2014).

\section{DISCUSSION}

Previous contributions in the field indicate that the most used antenna on the study of fluvial deposits are the $100 \mathrm{MHz}$ antennas (Best et al. 2003, Sambrook Smith et al. 2006, 2009). This device provides an intermediary frequency that balances good resolution and reasonable signal penetration (Tab. 1), noting that this relation is dependent on the surveyed depositional environment (Tab. 2). In addition to the $100 \mathrm{MHz}$ antenna, it was also employed a $200 \mathrm{MHz}$ antenna. However, it did not result in an expected higher resolution and had more hyperboles. As the $200 \mathrm{MHz}$ failed to provide usable profiles, this study favored the use of $100 \mathrm{MHz}$ antennas, which provide a resolution better suited for the comparison to known sedimentary features in the studied area.

The study of outcrops of the São Sebastiāo and Marizal formations in the Tucano Basin share some characteristics in common with previous surveys in active rivers, particularly the sedimentary structures interpreted in part of the radar facies. In fact, the main radar facies found in the Tucano Basin are frequently described in active fluvial systems elsewhere: inclined planar and trough cross-stratified sets, isolated channels, and high-angle cross strata in unit bars (e.g. Best et al. 2003, Skelly et al. 2003, Wooldridge \& Hickin 2005, Sambrook Smith et al. 2006 e 2009). The main difference regarding the study of outcrops concerns the depth of penetration. The literature shows signal penetration depths ranging from $6 \mathrm{~m}$, with a $200 \mathrm{MHz}$ antenna, in a survey at the Saskatchewan River (Sambrook Smith et al. 2006), up to $15 \mathrm{~m}$, in a survey at the Jamuna River with a $100 \mathrm{MHz}$ antenna (Best et al. 2003). The present study, on its turn, reached a depth of $4.5 \mathrm{~m}$ in lithified fluvial deposits with a $100 \mathrm{MHz}$ antenna. The penetration of the radar signal in eolian deposits was slightly deeper, reaching $5 \mathrm{~m}$ with the use of a $100 \mathrm{MHz}$ antenna, while a survey in eolian active systems reached the depth of $40 \mathrm{~m}$, with the use of a $30 \mathrm{MHz}$ antenna (Tatum \& Francke 2012).

The fact that unconsolidated sediments yield better penetration of the radar signal in comparison to sedimentary rocks indicates that diagenetic processes may be a factor of 
attenuation of the radar signal in sedimentary rocks. In a previous study, Daniels (2004) pointed that penetration of high frequency electromagnetic signals can be imparted by clayeyness, which can be a product of diagenetic processes, such as growth of clay minerals in pores or the alteration of detritic feldspar. The investigated deposits bear detritic feldspar in the framework of the sandstones, and the degree of weathering of the rocks is variable.

On the other hand, the resolution of some of the profiles was noticeably high, allowing the identification of sedimentary structures at a scale of $0.4 \mathrm{~m}$ in the case of cross-stratification. Previous studies (e.g. Best et al. 2003, Sambrook Smith et al. 2009), although using antennas with the same frequency, did not acquire resolution better than $1.0 \mathrm{~m}$.

The difference in penetration depths between eolian and fluvial deposits can be attributed to the higher heterogeneity of sedimentary facies in fluvial deposits, with frequent alternation of sandstone and mudstone beds, thus with higher clayeyness interfering with the radar signal, which contrasts to the eolian deposits, with better grain selection and lower clay and detritic feldspar content.

The same effects can explain difference in the answer to GPR between Marizal and São Sebastião formations. The Marizal Formation, with the exception of one outcrop, was particularly problematic regarding the acquisition of GPR data, due to low penetration of the radar signal in the outcrop or to low resolution of the signal. On the other hand, all the studied outcrops of São Sebastião Formation yielded GPR profiles where sedimentary structures could be recognized. According to previous studies (Figueiredo 2013, Freitas 2014, Figueiredo et al. 2015), the Marizal Formation sandstone has a more feldspathic composition than the São Sebastião Formation rocks, combined with the presence of immature conglomeratic composition in the former. As a result, the near surface weathering or previous diagenetic alteration of the investigated rocks could result in a higher content of neoformed clay minerals in the deposits of the Marizal Formation. In fact, the only outcrop of the Marizal Formation that was successfully imaged is interpreted as coastal deposits (Freitas 2014), which bears higher mineralogical maturity than the fluvial deposits.

\section{CONCLUSIONS}

Eight radar facies were recognized in the South and Central Tucano sub-basins in the São Sebastião and Marizal formations. Seven radar facies were recognized in the fluvial and eolian deposits attributed to the Sáo Sebastiáo Formation, while one was correlated to a discrete marine interval of the Marizal Formation.

The comparison between the studied outcrops and the profiles obtained through GPR survey attested the success of the GPR survey, with strong compatibility between the GPR profiles and the nearby outcrops. One of the most remarkable features of the GPR survey was the high resolution obtained in the study of the deposits, which were superior in resolution to what has been obtained in previous GPR surveys in unconsolidated sediments (e.g. Best et al. 2003, Sambrook Smith et al. 2009). Nevertheless, the GPR depth of survey did not penetrate beyond the mark of $5.0 \mathrm{~m}$ with $100 \mathrm{MHz}$ antennas, restricting the application of the methods and equipment to investigations to a depth that, despite being relatively shallow, are still on par to the scale of outcrop investigation.

The limitations imposed to the use of the GPR on continental siliciclastic rocks are directly related to amount of mudstone or clay minerals in the deposits. This limitation is the reason why the deposits of the Marizal Formation enabled profiles with very poor resolution or a too shallow penetration, in spite of the similarities between the deposits of the Marizal and São Sebastião formations.

Thus, given the satisfactory results obtained for the outcrops of the São Sebastião and Marizal formations, the use of GPR survey and radar facies interpretation as a tool for subsurface investigations has great potential for future stratigraphic and sedimentological studies in similar successions. However, it is important that the targeted sedimentary rocks do not record frequent interbedding of fine-grained deposits, appreciable content of clay cementation, or that the weathering of feldspathic and lithic fragments, if present, are not intense enough to result in strong clay mineral neoformation on the exposed outcrops. The use of $100 \mathrm{MHz}$ antennas for the study of sandstone deposits proved to be a good compromise between depth of investigation and resolution, allowing the investigations to reach decimeter scale detail, while maintaining a depth of penetration of the radar signal that is comparable to most outcrop investigations.

\section{ACKNOWLEDGEMENTS}

We are thankful to Marta Jacomo for help during fieldwork, and for the comments and suggestions provided by two anonymous reviewers. This paper received funding from the São Paulo Research Foundation (FAPESP) in the form of research grants and scholarships (2009/53363-8, 2009/52807-0, 2009/51766-8, 2010/51103-6, 2010/515590, 2013/01825-3, 2014/09800-2, 2014/16739-8). We also thank CAPES (PROEX-558/2011) for scholarships for Larissa Tamura, and CNPq for scholarship for Renato Almeida (301774/2012-9) and Liliane Janikian (301775/2012-5). This study is a NAP GEO-SEDEX contribution, with the institutional support of the University of São Paulo (PrPesq). 


\section{REFERENCES}

Almeida R.P., Turra B.B., Figueiredo F.T., Marconato A., Janikian L. 2015. Reconstructing fluvial bar surfaces from compound crossstrata and the interpretation of bar accretion direction in large river deposits. Sedimentology (online). doi: 10.1111/sed.12230.

Almeida Filho R., Miranda F.P., Yamakawa T., Bueno G.V., Moreira F.R., Camargo E.G., Bentz C.M. 2002. Data integration for a geologic model of hydrocarbon microseepage areas in the Tonã Plateau region, North Tucano basin, Brazil. Canadian Journal of Remote Sensing, 28(1):96-107.

Alvarado-Ortega J. \& Brito P.M. 2010. A new ichthyodectiform (Actinopterygii, Teleostei) from the Lower Cretaceous Marizal Formation, northeast Brazil. Paleontology, 53:297-306.

Amaral C.R.L \& Brito P.M. 2012. A new Chanidae (Osthariophysii: Gonorynchiformes) from the Cretaceous of Brazil with Affinities to Laurasian Gonorychiforms from Spain. PLos One, 7(5)e37247. doi:10.1371/journal.pone.0037247

Annan A.P. 2001. Ground Penetrating Radar Workshop Notes, Sensors \& Software Inc, $192 \mathrm{p}$.

Arai M. 2014. Aptian/Albian (Early Cretaceous) paleogeography of the South Atlantic: a paleontological perspective. Brazilian Journal of Geology, 44(2):339-350.

Best J.L., Ashworth P.J., Bristow C.S., Roden J. 2003. Three-dimensional sedimentary architecture of large, mid-channel sand braid bar, Jamuna River, Bangladesh. Journal Sedimentary Research, 73(4):516-530.

Carrera S.C. 2015. Arquitetura deposicional e proveniência da Formação Marizal nas sub-bacias Tucano Sul e Central, BA. MS Dissertation, Instituto de Geociências, Universidade de São Paulo, 147 p.

Corbeanu R.M., Soegaard K., Szerbiak R.B., Thurmond J.B., McMechan G.A., Wang D., Snelgrove S., Forster C.B., Menitove A. 2001. Detailed internal architecture of a fluvial channel sandstone determined from outcrop, cores, and 3-D ground-penetrating radar: Example from the middle Cretaceous Ferron Sandstone, east-central Utah. American Association of Petroleum Geologists Bulletin, 85(9):1583-1608.

Costa I.P., Milhomem P.S., Bueno G.V., Silva H.S.R.L., Kosin M.D. 2007a. Sub-bacias de Tucano Sul e Central. Boletim de Geociências da Petrobras, 15(2):433-443.

Costa I.P., Milhomem P. S., Bueno G.V., Silva H.S.R.L., Kosin M.D. 2007b. Sub-bacia de Tucano Norte e Bacia de Jatobá. Boletim de Geociências da Petrobras, 15(2):445-453.

Daniels D. 2004. Properties of materials. In: Daniels D. (eds) Ground Penetrating Radar. 2 ed. Institution of Engineering and Technology, 73-246 p.

Figueiredo F.T. 2013. Proveniência e arquitetura de depósitos fluviais das Sub-Bacias Tucano Central e Norte, Cretáceo (BA). PhD. Thesis, Instituto de Geociências, Universidade de São Paulo, São Paulo, 193 p.

Figueiredo F.T., Almeida R.P., Freitas B.T., Marconato A., Carrera S.C. Turra B.B. 2015. Tectonic activation, source area stratigraphy, and provenance changes in a rift basin: the early Cretaceous Tucano Basin (NE- Brazil). Basin Research, 1-13. doi 10.1111/bre.12115.

Freitas B.T. 2014. A Formação Marizal (Aptiano) na Bacia do Tucano (BA): Contribuições à análise da arquitetura de depósitos fluviais e implicações paleobiogeográficas. PhD Thesis, Instituto de Geociências, Universidade de São Paulo, São Paulo, 175 p.

Gawthorpe R.L., Collier R.E., Alexandre J., Bridge J. S., Leeder M.R. 1993. Ground penetrating radar: application to sandbody geometry and heterogeneity studies. In: North C.P. \& Prosser D.J. (eds). Characterization of Fluvial and Aeolian Reservoirs. Geological Society Special Publication 73:421-432.
Jol H.M. \& Bristow C.S. 2003. GPR in sediments: advice on data collection, basic processing and interpretation, a good practice guide. In: Bristow C.S. \& Jol H.M. (eds.). Ground Penetrating Radar in Sediments. Geological Society Special Publications, 9-27 p.

Magnavita L.P \& Cupertino J.A. 1988. A new approach to the geological configuration of the Lower Cretaceous Tucano and Jatobá Basins. Revista Brasileira de Geociências, 18:222-230.

Magnavita L.P. 1992. Geometry and kinematics of the RecôncavoTucano-Jatobá rift, NE Brazil. PhD Thesis, University of Oxford, Oxford, $493 \mathrm{p}$.

Magnavita L.P., Davison I., Kusznir N.J. 1994. Rifting, erosion, and uplift history of the Recôncavo-Tucano-Jatobá Rift, northeast Brasil. Tectonics, 13:367-388.

Magnavita L.P., Destro N., Carvalho M.S.S., Milhomem P.S., Souza-Lima W. 2003. Bacias Sedimentares Brasileiras: Bacia Tucano. Fundação Paleontológica Phoenix, Ano 5, Série Bacias Sedimentares, número 52.

Milani E. \& Davison I. 1998. Basement control and transfer tectonics in the Recôncavo-Tucano-Jatobá rift, Northeast Brazil. Tectonophysics, 154:41-70.

Neal A. 2004. Ground-penetrating radar and its use in sedimentology: principles, problems and progress. Earth-Science Reviews, 66:261-330.

Porsani J.L. 2011. Método GPR: Aplicações. Escola de Verão de Geofísica Aplicada, Instituto de Astronomia e Geofísica, Universidade de São Paulo, 27 p.

Reis M.A.F., Dino R., Pereira, E., Antoniolli, L 2007. Dados palinológicos da Formação Marizal da Bacia do Recôncavo, Nordeste do Brasil. In: Carvalho, I. S., Cassab, R. C. T., Schwanke, C., Carvalho, M. A., Fernandes, A. C. S., Rodrigues, M. A. C., Carvalho, M. S. S., Arai, M., Oliveira, M. E. Q. (Orgs.). Paleontologia: Cenários de Vida. 1ed. Rio de Janeiro. Editora Interciência, 229-573.

Reynold J.M. 1997. Ground Penetrating Radar. In: Reynolds J.M. (eds). An introduction to applied and environmental geophysics. Chichester John Wiley, p. 682-745.

Sambrook Smith G.H., Ashworth P.J., Best J.L., Woodward J., Simpson G.J. 2006. The sedimentology and alluvial architecture of sandy braided South Saskatchewan River, Canada. Sedimentology, 53:413-434.

Sambrook Smith G.H., Ashworth P.J., Best J.L., Orfeo O., Parsons D.R. 2009. The sedimentary and alluvial architecture of large braid bar, Rio Paraná, Argentina. Sedimentary Research Journal, 79:629-642.

Santos C.C., Reis C., Pereira A.J. 2010. Projeto Bacia do Tucano Central. Salvador: Companhia de Pesquisa de Recursos Minerais, 88 p.

Silva O.B., Caixeta J.M., Milhomem P.S. 2007. Bacia do Recôncavo. Boletim de Geociências da Petrobras, 15(2):423-431.

Skelly R.S., Bristow C.S, Ethridge F.G. 2003. Architecture of channelbelt deposits in an aggrading shallow sandbed braided river: the lower Niobrara Rives, northeast Nebraska. Sedimentary Geology, 158:249-270.

Tatum D.I. \& Francke J. 2012. Constructing hydrocarbon reservoir analogues of aeolian system using ground penetrating radar. Applied Geophysics Journal, 81:21-28.

Viana C.F., Gama Junior E.G., Simões I.A., Moura J.A., Fonseca J.R., Alves R.J. 1971. Revisão estratigráfica da Bacia do Recôncavo/ Tucano. Boletim Técnico da Petrobras, 14(3-4):157-192.

Wooldridge C.L \& Hickin E.J. 2005. Radar architecture and evolution of channel bars in wandering gravel-bed Rivers: Fraser and Squamish rivers, British Columbia, Canada. Sedimentary Research Journal, 75:844-60.

Arquivo digital disponível on-line no site www.sbgeo.org.br 